\title{
Social Psychological Interventions to Reduce the Number of Violence against Women in Indonesia \\ Tommy Prayoga
}

Department of Psychology, Bina Nusantara University, Indonesia

Annisa Chika Noviardi

Department of Psychology, Bina Nusantara University, Indonesia

Caroline Winata

Department of Psychology, Bina Nusantara University, Indonesia

Gunawan Saputra

Department of Psychology, Bina Nusantara University, Indonesia

Vivi Angelina

Department of Psychology, Bina Nusantara University, Indonesia

Jeremy Kristianto

Department of Psychology, Bina Nusantara University, Indonesia

Rahayu Crystal Himawari

Department of Psychology, Bina Nusantara University, Indonesia

Sharron Sharron

Department of Psychology, Bina Nusantara University, Indonesia

Juneman Abraham

Department of Psychology, Bina Nusantara University, Indonesia Email: juneman@binus.ac.id

Doi:10.5901/mjss.2015.v6n4s2p285

\section{Abstract}

This article aimed at discussing the interventions that have been made in the fight against gender injustice, and specifically the domestic violence which is widespread in Indonesia. There are three social intervention solutions conducted during October 2014 to January 2015 in Jakarta, the capital of Indonesia, as part of Social Psychology and Psychological Intervention Course Program that will be discussed in detail, namely 1) intervention toward the observer's (bystander's) attitude toward the violence to be a preventer of the violence (or, to be an upstander), 2) intervention eliminating women objectification among men, and 3) intervention reducing verbal violent behavior against women. All those three will be discussed in an intervention methods of PATH, a model constructed by Abraham P. Buunk and Mark Van Vugt (2013) consisting of four stages, i.e. Problem formulation (Problem), Analysis and explanation (Analyze), Test stages (Test) and Intervention implementation (Help). The intervention targets are the students, the late teens, and the young adults through 1) Handbook of Violence Prevention to offer support and assistance for the actual and potential victims of domestic violence, 2) the campaign via radio mass media for prevention of women objectification, as well as 3) the delivery of contemplative messages through shirt and pin for verbal abuse prevention.

Keywords: psychology of violence; PATH model; domestic; upstander; verbal abuse 


\section{Introduction}

More than twenty years ago, violence against women is not considered as a phenomenon that attracts international attention, until the end year of $80 \mathrm{~s}$ on which there are number of women's movement organizations that never stopped searching for public and international attention to the issue of physical, physiological and economic violence against women (Alhabib, Nur, \& Jones, 2009). A literature review by Alhabib, Nur, and Jones (2009) which covered 134 studies from North America, Asia, Australia, South America, Europe and the Middle East showed that violence against women has become an epidemic, and not even a race, ethnic nor socio-economic group is immune to it. This global phenomenon of human rights violations put women at a very unfavorable position (Windiani, Astuti, Fitriyah, \& Hermini, 2013).

We could consider the following facts: (1) Tucker-Ladd (2011) stated that in America, 30\% of pregnant women died because they were killed (Chang, Berg, Saltzman, \& Herndon, 2005) and were mostly done by their partners; one of eight high school teenagers is currently in a relationship that involves violence; one of five women have been raped and the oppression rate of the female in a romantic relationship is very high; (2) Sarookhani and Daneshian (2014) noted that the violences committed by husbands are as much as $29 \%$ in Nepal, 57\% in India, 26\% in Kazakhstan, and 56\% in Turkey; (3) Carey and Torres (2010) showed La Violencia terminology to describe the era of massacres, oppression and massive rape toward women of various ages by men from various populations in South America during the 20th century; (4) Wahed and Bhuiya (2007) noted that women in Bangladesh have to withstand blows, humiliations and daily tortures by their husbands for failing to follow their husbands' orders, even those practices have already been considered as "common" practice.

Some of the examples above are just small fractions of the millions cases of violence against women done by men. Violence caused by this gender bias is often called "gender-based violence" (Tisyah \& Rochana, 2013) because women were the main victims (e.g. Hartono, 2014; Windiani, Astuti, Fitriyah, \& Hermini, 2013; Ludemir, Lewis, Valengueiro, de Araújo, \& Araya, 2010), even women with disabilities (Healey, Humphreys, \& Howe, 2013) and pregnant women are no exceptions (Ludemir, Lewis, Valengueiro, de Araújo, \& Araya, 2010). Sarookhani and Daneshian (2014) mentioned that the violence may include physical, emotional, financial and social violence. One specific form is domestic violence committed by close people such as spouse or family member (McMillan, as cited in Lamont, 2013) which is coercive and pressing. The effects of such violence are varied, starting from psychiatric disorders associated with anxiety and depression (Marchira, Amylia, Winarso, 2007) up to suicidal thoughts, lowered self-esteem, panic attacks, stress, difficulty in concentrating, increase of alcohol consumption, and self-injuring behaviors (Smith, 2011).

The term "domestic violence" has been recognized by the people of Indonesia, mostly in terms of Violence Against Women or Domestic Violence, which is a new breakthrough terminology in the legal of human rights violation protection in Indonesia, namely Law of The Republic of Indonesia No. 23, Year 2004, of the Elimination of Domestic Violence (Aisyah \& Parker, 2014). Article 1 Paragraph 1 of the Law defines domestic violence as any action against someone-especially women-which causes misery or suffering in physical, sexual, psychological, and/or negligence of household including threats to commit acts, compulsion or deprivation of liberty which are against the law within the scope of household (Hartono, 2014). Many other terms used for more specific criteria, such as violence in courtship (e.g. Tisyah \& Rochana, 2013; Cook-Craig et al., 2014) and sexual intercourse violence (e.g. Banyard, Moynihan, \& Plante, 2007; Salazar, Vivolo-Kantor, Hardin, \& Berkowitz, 2014), but term will be used later in this paper is domestic violence which includes some of those things.

Domestic violence in Indonesia as in other parts of the world was already occurred frequently. Not a few academics that went to the field investigating the phenomenon surrounding the domestic violence that happened in Indonesia. As the result, a variety of violence, especially that of physical and psychological, found to be occurred in various regions of Indonesia. From a population of 217 million, 11.4 percent of them (or about 24 million women population), especially in rural areas, confessed that they had experienced violence, and mostly in the form of domestic violence such as assault, rape, abuse, or a cheating husband (Kompas, 27 April 2000, as cited in Windiani, Astuti, Fitriyah, \& Hermini, 2013), and it's only a very small amount number compared to what should be reported. During the last three years, approximately 100,000 domestic violence cases were reported; in 2011, a total number of 113,878 cases reported with a record of $97 \%$ violence cases committed by husbands (Komnas Perempuan, as cited in Aisyah \& Parker, 2014).

In the identification and prevention efforts, a variety of risk factors has been identified. For example, the identifications showed that what affecting in the husbands' side are age, education and psychosocial behaviors such as the tendency to get angry, fighting and drinking alcohol; while on the wife's or female's side, the influencing factors are economic (in)dependence and the viewpoints on traditional gender norms (Hayati, Hogberg, Hakimi, Ellsberg, Emmelin, as cited in Hayati, Eriksson, Hakimi, Högberg, \& Emmelin, 2013). These factors, especially the traditional viewpoints of 
gender norms, greatly hinder the identification and prevention of epidemic prevalence of this violence. For example, the Makassar women are required to maintain their family honor (siri). If they disclose their husbands' violent attitude then it will destroy the dignity, so that the women will be punished or considered shameful (Aisyah \& Parker, 2014). Another example is the Javanese women, that in the same reasons they have to preserve the norm of njaga praja, that is to maintain the honor of husband and family, so that they should keep silent to the public for the violence acts committed by their husbands (Djohan, as cited in Hayati, Eriksson, Hakimi, Högberg, \& Emmelin, 2014).

Violence is an attack (assault) to both one's physical and mental/psychological integrity. Violence against humans can be occurred due to a variety of sources; one of which is violence that derived from gender assumptions. Such violence is called "gender-related violence" which is essentially caused by the inequality of power in society. There are many reasons why the dignity of women has been being abused or experiencing harassment. One reason is the socially constructed stereotype. Stereotypes are labeling of certain parties that always lead to harm to others and cause injustice. One of the stereotypes is the stereotype derives from the gender assumption. That is why many forms of injustice towards gender (which are mostly women) originate from the attached stereotype. It is also a very discrediting condition of women. For example, there is a view that what was said by men is regarded higher than what was said by women because the men's position and dignity are greater, as well as several other conditions.

Every country has his/her own gender issues, just the same with Indonesia. However, the eradicating efforts in some countries have surpassed the prevalence of the occurred domestic violence. The intervention target is diverse, but the micro-conventional means such as providing counseling, seminars and protest against gender inequality have been viewed as "old fashioned" and thus abandoned. Many breakthroughs from creative campaign efforts that proved to be effective out there, but unfortunately it has not been all optimized in Indonesia.

The bright side in those dark facts is that not all Indonesian citizens remain silent facing the chronic domestic violence against women. Many parties opposing the violence even have tried to do intervention to fight against this problem. A community that has been quite active in conducting this prevention action is the college students group, particularly that of Psychology Department. This article was written with the purpose to expose the efforts and interventions programs conducted during October 2014 to January 2015, by the authors from Bina Nusantara University, Psychology Department against the gender injustice based on the PATH intervention model by Buunk and Van Vugt (2013). Three intervention solutions are analyzed in this article, namely: 1) Enable the passive observer (i.e. bystander); 2) Stop the women objectification, and 3) Stop verbal violence against women. Hopefully, it will later bring benefits to the community and practitioners in the form of ideas, enlightenment and encouragement for joining initiatives to fight against gender inequality.

\section{Methods: PATH Model of Social Intervention}

The three of intervention solutions discussed in the descriptive article implemented by using a PATH model which are Problem, Analysis, Test and Help. This model is an intervention model developed by Abraham P. Buunk and Mark Van Vugt (2013). There are four stages namely Problem definition formulation (Problem), Analysis and problem explanation offering (Analyze), Developing and testing process models (Test), and Implementing interventions (Help). At the stage of Problem, it speaks out of the development of the problem definition appropriate to the faced problems. The strategy is to answer the six key important questions, i.e. 1) "What's the problem?", 2) "Why is it a problem?", 3) "The problem is for whom?", 4) "What are the possible causes of these problems?", 5) "Who is the target group?", and 6) "What are the key aspects of the problem?". Once they are summarized into an appropriate discourse, then the intervention process moves to the analysis step.

In the analysis phase, the first thing to do is to specify the outcome variable, or a single variable to be changed in order to achieve the objectives of the intervention. Outcome variables can be variables of specific behavior, attitude, cognition, and affection that are relevant to the issues and be sustainable. After determining the outcome variable, then the Divergent Phase is held. It aims to provide as much as possible explanations to the problem by using free association method, or observations and interviews, or theoretical approaches. After various explanations have been made, then it continues on Convergent Phase which aims to reduce repetitive, irrelevant and invalid descriptions. The next stage is testing, which is the construction of a process model as the representation of the explanatory variables (obtained from the analysis) and their relationships therein with the outcome variables.

The last is the assistance (help) stage, as an intervention stage that is getting ready to implement the intervention. Firstly it has to frame the magnitude effects of explanatory variables that play roles in influencing the outcome variables. Then the methods of selection are made to have the best strategies and delivery lines that are match to the outcome variable. Only then, intervention is implemented by mapping the flow of design, implementation, and execution. 


\section{Activate Passive Bystander}

\subsection{Problem}

In the case of Indonesian domestic violence, which is increasingly in the prevalence, it demands surrounding participation of the bystander to take part in the prevention. Unfortunately, many studies have reported that not many individuals who witnessed (i.e. bystander) or obtain domestic violence incident information lend their hands to help the eyewitness victims, even when the number of people who witnessed were beyond the performer of violence. It is called the "bystander effects" or observer effects (what). If the domestic violence victims are reluctant to report the crime offenders, and even more difficult for the offender to surrender or stop conducting the violence, then the only hope for the victim is the person(s) who witnessed the incident trying to prevent and helping the victims from the physical and emotional injured risk. If the observer effect is not eliminated, the cycle of violence obviously will not stop and the victims will continue to be exposed with the oppression risk, even in the public (why). It is certainly very harmful to the victims and causing sorrow to people who can actually help but did not take the action (who).

The reason behind the bystander effect is the diffusion of responsibility to help among those who witnessed. There may also be a distant relationship between the observers and the victims. The more spreading of the responsibility and the more distant the relationship between the observers and the victims, then the perceived motivation and empathy in the bystander's side will be lesser so that the probability to take initiative action is also minimal (causes). Thus, it is quite wise and pivotal to provide the observers-who can be anyone who witnessed the incident of violence-with the intervention knowledge to take the initiative to intervene against domestic violence (target). Problems of the observer effect that hinder the domestic violence prevention is a very serious but, fortunately, solvable problem because it has a concrete and clear psychosocial dimension aspects to be investigated and intervened (aspects).

\subsection{Analyze}

Based on the definition of the above problems, the outcome variable that is desirable to be changed from the first intervention solution is "increasing tendency of the observer (bystander), who were exposed directly or indirectly to a domestic violence incident, to peform the helping behavior". The first intervention is to analyze the problems using topical strategies, that is to have explanation about the causes of the bystander effect in the context of domestic violence and its relationship with the helping behavior, combined with the general theory strategy using Theory of Planned Behavior (TPB; Fishbein \& Aizen, as cited in Powell, 2011) to explain the reason of an observer to act when confronted with domestic violence. Interventions using bystander approach in the student community meant to improve the helping behavior when witnessing domestic violence.

The approach was done based on the idea that people who witnesses the domestic violence incident (or, bystander) is obviously the very important party in the effort of preventing a violence act, such as ensuring that the violence is reported to the authorities, or ensuring that the violence victims get proper assistance (Planty, as cited in Cismaru, Jensen, \& Lavack, 2010). The author also revealed the presence of several factors that influence the helping behavior. One of them is the responsibility diffusion among observers, so that the feeling of responsibility becomes less among them (Darley \& Latane, as cited in Koon, 2013; Chevron \& Brauer, as cited in Coker et al., 2011; Powell, 2011).

The findings of the studies by Banyard, Moynihan, and Plante (2007), Banyard (2008), and Coker et al. (2014) indicated that cognitive and affective factors such as knowledge and attitudes towards violence also plays important roles in the initiation of the relieving or helping efforts. Knowledge and the regarded attitude is closely related to the acceptance and perception of the encountered violence (Lonsway, Cortina, \& Magley, as cited in McDonald \& Flood, 2012). Webb and Sheeran (as cited in McCauley et al., 2013) also found that one's intention has great influence, especially for men to become active observers. At last, Berkowitz and Daniel (as cited in Powell, 2011) proposed that those factors predicting the helping behavior could be influenced by social norms. Clarke (as cited in Powell, 2011) described that when the social norm is in conflict with situations, such as the norm of "do not interfere other people's problems", then it will give the implication on hesitation and lowering the tendency to help.

Theory of Planned Behavior or TPB is used by the authors to include a number of factors (mentioned above) that influence behavior in terms of affective and cognitive factors, social norms, and intention (Fishbein \& Ajzen, as cited in Powell, 2011). Thus, to encourage an observer to become active, according to the TPB, is to make a change in the individual's attitudes and beliefs, perceptions of social norms, perceptions of his/her ability to provide assistance, as well as making the change in the attitudes and behaviors embraced by others (Powell, 2011).

Finally, this stage also determined the selection of the most likely alternatives to be intervened. The authors 
decided that among others they are intention, a sense of responsibility, knowledge of how to intervene effectively, and the moderating roles of the social norms.

\subsection{Test and Help}

At the trial phase, the authors made the mapping of variables mentioned above and performed reviews based on the scientific journals for each variable. It was found that the most effective intervention plot (having the largest effect size) is that of the correlation between knowledge and attitude; attitude and the willingness to help (Banyard, 2008); attitude and the intentions to help (Laner et al., as cited in Banyard, 2008) as well as of the relationship between intention and the possibility to help (McCauley et al., 2013). Compilation of the magnitude effects showed that these variables have been the most optimal and feasible variables which are modifiable, so the chosen intervention path targeted these variables. This path was supported by previous studies regarding TPB which is targeting changes in individual's attitudes and beliefs, perceptions of social norms, perception of the individual's ability to provide assistance, and attitudes as well as behavior adopted by others (Powell, 2011) which proved to be quite effective. The next step is to design the interventions.

First, the intervention target was set among the students. The reason is because students are among the most educated, most open-minded thinker. Their thoughts are more fluent and their behaviors are easily changed using logical and other appropriate approaches compared to other age groups. Therefore, when they are given appropriate information regarding the prevention of domestic violence, the students are expected not only to change their opinions, but also to be an upstander, which is an agent of change that can spread the spirit of violence prevention.

Aiming to improve the helping behavior based on knowledge and attitudes, the authors decided to create a Handbook of Violence Prevention (HVP; see Figure 1 and Figure 2) containing information about prevention techniques and other details that can raise self-efficacy and build empathy within oneself which would be needed by a bystander in order to transform his/her act to be an upstander. There are various kinds of content, i.e. reminders about prevalence of domestic violence, prevention tips, self-assessment questionnaire of efficacy, methods of how to become upstander, how to give support to victims of violence, centers and numbers to call when the handbook readers are faced with domestic violence. The reader is expected to have better preparations for domestic violence which is getting worse nowadays in terms of quantity and quality.

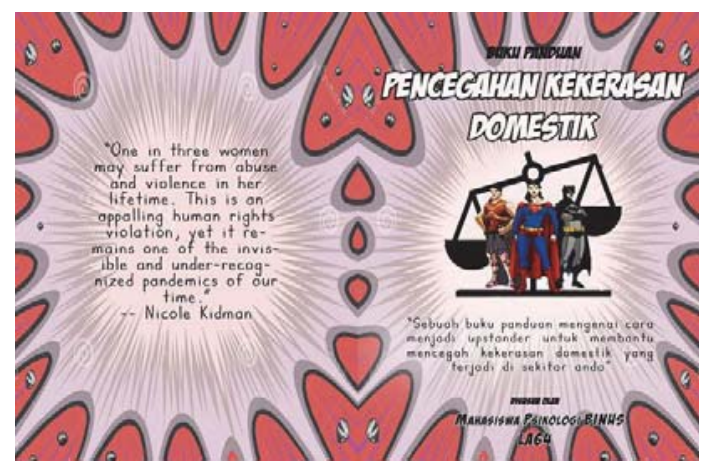

Figure 1. Handbook of Violence Prevention

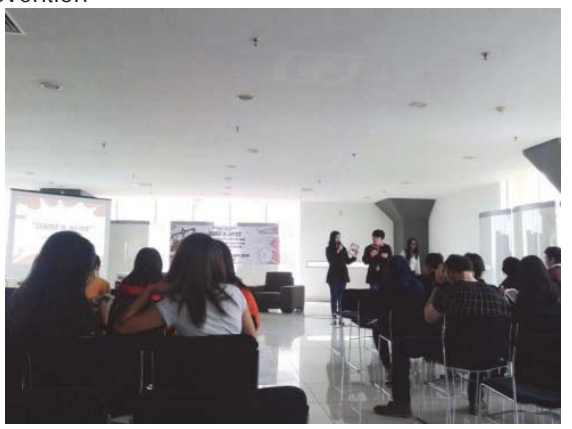

Figure 2. Socialization of Handbook of Violence Prevention through the Seminar on Gender in Justice 


\section{Fight Against Objectification of Women}

\subsection{Problem}

Over the past 14 years, from 3,627 cases of the revealed women violence, about $26 \%$ of them are in dating violence and rape. Those cases are inline with the viewpoint that tends to be more beneficial to the men and degrading the women. The idea has been implemented in the public system, in which the social construction supports the emergence of women objectified behavior (what). This viewpoint leads to threaten the women (for whom) who often face aggression act, harassment, and discrimination from the men, such as violent behavior in the interpersonal relationships and even makes the women as the bet objects of the men (why). Gender bias that disadvantages women persists due to the social construction that has been implanted in society for centuries, from culture to religion/beliefs verses embraced by the community (cause). This has led the existence of prejudice against women by men, thus giving rise to the self-concept to dominate or objectify women (key aspect).

The gender bias that leads to the behavior of the objectification of women can be intervened through the action aiming at justifying the right and fair viewpoint of gender appreciation to the freshmen and sophomores (target). It can be conducted by focusing on increasing students' awareness through the delivery of the information by the radio broadcasting of the related topic (key aspect). By this intervention method, freshmen and sophomores will have awareness about the "deviated" social construction in the form of women objectified by men existing in the environment, and participate in removing or overcoming of women objectified attitude by men in the society (target).

\subsection{Analyze}

The second intervention solution is more focused on the attitudes and the public opinion towards concept of woman which is affected very much by the patriarchal era, viewing women as "second class" people, objects, not a whole or intact human. Based on the problem definition, goal or outcome variable of the intervention solution would be to reduce behavior sustaining the objectification of women by men. Using the method of association between issues related to the outcome variables (Buunk \& Van Vugt, 2013), the authors developed several explanation of women objectified phenomena, namely 1) The presence of misperceptions as well as the demands and influences from the social environment supporting the objectification, 2) Establishment or formation of self-concept, mindset and attitude towards women, 3) Experience of dealing with women, and 4) Consequences gained from those experiences.

According to the authors, the explanatory variables contributing to these reasons are 1) Social norms, including how we think and behave in general, 2) The self-concept of men who consider themselves superior to women, 3) Establishment of evaluation and description of individual's assessment toward women, or representation of concepts or constructs in the men's head about women, 4) Normative effect that justifies the behavior of women objectification, 5) Conformity to community group which used to objectify the women, 6) Social feedbacks rewarding or reinforcing the objectification responses, such as a sense of control over women, acceptance or inclusion by groups advocating women objectification, and 7) Sense of involvement and unity toward a patriarchal movement. It is proposed that by intervening those variables, the authors are able to reduce the behaviors of objectifying the women.

\subsection{Test and Help}

Variables extracted from the analysis phase have different effect sizes depending on the outcome variables. Through the mapping of the magnitude effects, the authors obtained four key variables that most influential on the objectification of women that are suitable as the intervention targets. First, the self-concept of man has a large enough effect size on the formation of the descriptive conception of women. Second, the establishment of the description has a considerable influence on the objectification of women. Third, the existence of supporting actions in the form of reinforcement from the environment approving the behavior of objectification. Fourth, conformity occurring within the men making them to easily follow objectification.

To make the effort of the intervention on the basis of that reasoning, the authors chose a path of intervention that is quite effective, namely Radio broadcast. The reason, radio is one medium that is often used by today's society. Regardless of the television popularity, radio is heard everywhere and almost in all circles so that it is effective to be used as an intervention groove. In this intervention, the authors are in collaboration with one of the leading radio of a private university in Jakarta (BVoice Radio by Bina Nusantara University; hear also www.bvoiceradio.com site). The target is the entire listeners, especially students that classified as young people. Strategy and method used is to perform live 
streaming conversations around domestic violence with the topic about women objectified (see Figure 3). The authors conducted a discussion around the prevalence, reasons and events on women objectified. We argued that the objectification has no justifiable foundation, that the objectification is a totally incorrect attitude and action. The intervention is also supported by the Twitter social media (@BVoiceRadio; see Figure 4); because the radio provided an opportunity for its listeners to ask the authors openly through its Twitter account. The radio also broadcasted the discussion results bit by bit on its Twitter account.

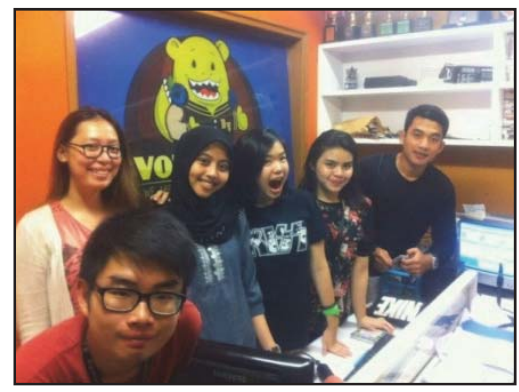

Figure 3. BINUS Psychology Department @BVoiceRadio Campaigning Gender Equality
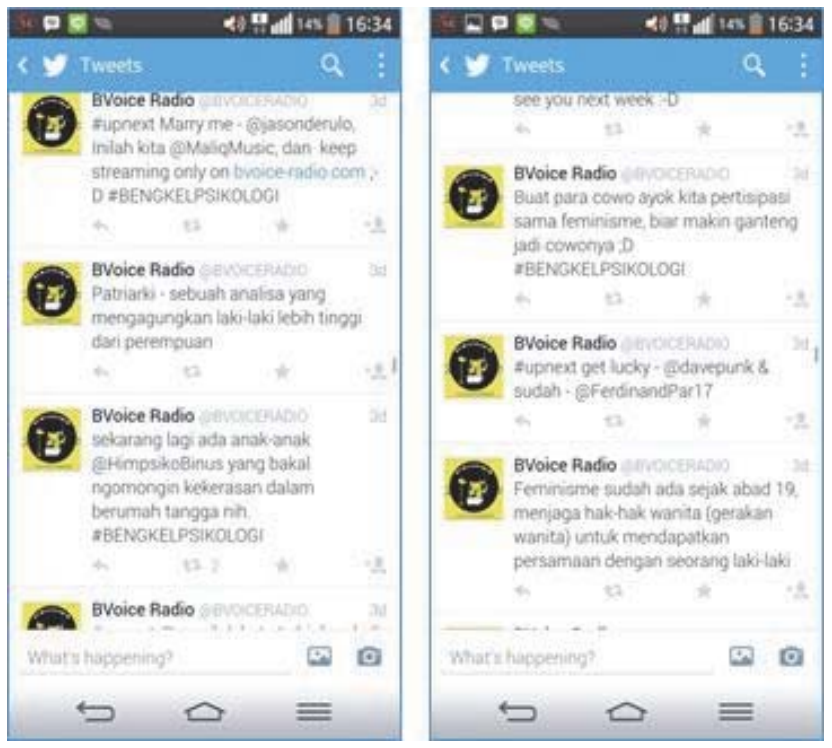

Figure 4. Twits about Violence Against Women at BVoice Radio

\section{Stop the Verbal Abuse}

\subsection{Problem}

Violent words (verbal abuse) are all forms of speech acts that have the nature of insulting, yelling, cursing, scolding and frightening by spending inappropriate verbal words which bring out effect on violence causing a very harmful to the victim, whether physically or mentally. The research results conducted by Rifka Annisa Women's Crisis Centre (Rifka Annisa, 1995 ) on domestic violence towards 262 respondents (wives) showed that $48 \%$ of wives experienced verbal abuse, and $2 \%$ experienced physical violence. Although it may not have a physical impact, verbal abuse can damage women psychologically. According to Risman (as cited in Dani, 2006), verbal abuse may cause deeply injuries in the lives and 
feelings of children more than the rape.

According to Suryakusuma (as cited in Ribka, 1998), the psychological persecution effects for many women are more severe than the physical effects. Fear, anxiety, fatigue, post-traumatic stress disorder as well as eating and sleeping disorders are long term reactions of violence acts. It has to be anticipated that by the verbal violence, those symptoms will keep on existing in women, even can also be contagious to other parties. As in regard of the society norms, the use of addictive stuff and the contradictory perspectives in gender roles between involved parties were affecting very much the verbal violence.

Men are the most potential party to do verbal violence against women. It is mostly found on the issues of verbal abuse in dating, household, as well as in the daily life of the community. Thus, the main aspects that should be improved are the perception and attitude of the verbal violence actors, especially men.

\subsection{Analyze}

Based on the problems formulated above, the outcome of intervention that was determined by the authors is to reduce verbal violence against women. It is expected that by intervening it, the communities, especially men, understand the negative impacts that would arise from the verbal violence behavior and will not do verbal violence in the future. Using free association method (Buunk \& Van Vugt, 2013), the authors presented several possibilities of description for this problem. First, there is a sense of superiority by men about their gender positions. Second, the presence of cognitive distortion or dysfunction, which is the viewpoint that women indeed should be the subject of derision. Third, the release of aggressive drive or resentment by self-satisfying ill verbal acts. Fourth, many examples of verbal abuses that occurred in the community so that they had been regarded as "natural".

There are also the roles played by the variables included in the Social Identity Theory (SIT; Tajfel, 1978) explaining prejudice, discrimination, social change and conflict between groups. The authors explained that in this verbal violence issue, the phenomenon of social categorization of men and women having different social gender identifications occurs. According to those differences, men/males and women/females divided into in-group and out-group. In this case, verbal abuse toward women happened following what was described by Burke (2006) as a self-enhancement and positive distinctiveness strategy done by the men's in-group members. Men use verbal violence to increase the sense of superiority and to distinguish themselves from the group of women with the reason of maintaining the men's self-esteem and dignity. This occurs due to the lack of adequate understanding and empathy about the consequences of verbal abuse (thus it is considered as natural), and lack of awareness about the worthy of genuine self-esteem, dignity, and about the way to defend them correctly and healthily.

\subsection{Test and Help}

The authors moved on from the idea based on the analysis results stating that the main cause of verbal violence by men is a negative perception against women that lead to discriminatory act such as the transformation of violence against women into verbal attacks. It was also caused by the lack of awareness of the adverse effects of such behavior. Iskandar (2010) found that the greater positive attitude toward gender discrimination, the higher the tendency of verbal violence. Paramita (2010) also found a positive correlation between the levels of knowledge and the behaviors of handling a problem. The lack of awareness of a poor act or habit causes the higher opportunity of (re-)doing that kind of act.

In the intervention, the authors wanted to implant certain self-concept to the verbal abuser. The process is to choose a path of intervention that attracts attention, which can be taken anywhere and stimulate people's contemplation, i.e. on the Shirt and Pin. Through thought provoking words printed in the shirt and pin, the authors wanted people to pay attention to the content of the clothes wherever he/she goes. Good and simple design will make people interested and think. Sentences to be printed were "Words can kill" or "Words can hurt or heal" and "What did you say today?" (see Figure 5).

The target of intervention is among college students and young adults because numbers of the verbal violence behavior are committed among them respectively. In addition, because of open-mindedness nature of the students, it is anticipated as easier to raise an awareness of the right mindset about social group identity to the students. The strategy is the "fear communication" so that people are aware that verbal abuse is totally wrong and has serious destructing impacts. Through the using of the pin, it is expected that when they go anywhere using those attributes, many people will read it and internalize the message. 

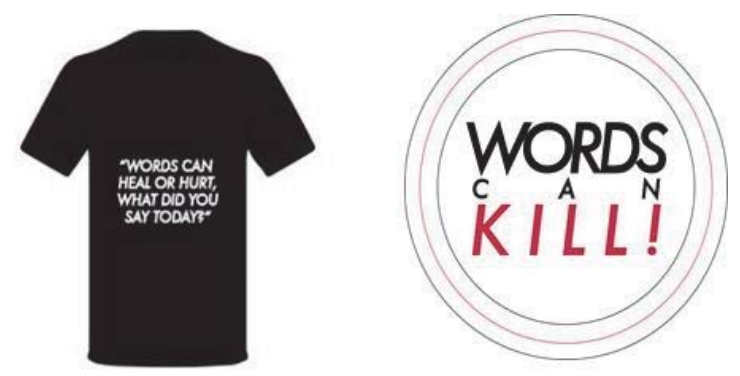

Figure 5. Shirt and Pin for Social Intervention

\section{General Discussion}

The three interventions discussed above are stand out parts of many other interventions against gender-based violence in Indonesia. Considering the high prevalence of violence case and the increasing of discriminative behavior incidences, all of the three have indeed stimulate actions to address the factors of the developing gender discrimination, particularly against women.

First of all, from the last two interventions, it was indicated that there were certain fundamental mindset factors among males, e.g. perception toward women as objects, contributing to gender injustice. Women as materials of bets, object of derisions, objects of social exchanges, among others are situations containing reminiscences about the primordial societies in ancient times. In the modern era, it is no longer "functional" and should be destroyed so that not only gender justice and humanitarianism will be achieved, but also that kind of old-fashioned mindset to not inhibit the growth of appropriate moral thoughts.

Second, in terms of behavior, violence that is more widespread in every day's life of women is not physical violence, but verbal. In the midst of the remaining law's treatment toward physical violence, because of the great law enforcement pressure from the social, the verbal abuse becomes a new alternative channel of aggressive compensatory behavior. Based on the mindset of women as an object and inferior sex, women are associated as the weak, stupid and just a composition of reproductive organs thus are not as worth as men in any field, so that many things done by women are considered wrong, untrue and inappropriately "manly". Then ridicules, insults and anger by the "ancient patriarchal advocates" appeared in the public.

Obviously, many people are aware of both issues (that women are object and inferior sex), but regardless of how many cases are being reported, how many hundreds of agencies and organizations formed to eradicate violence, those kinds of mindset and treatment will not disappear entirely. That is because the agencies and organizations are only the secondary prevention, or prevention happening when violence has occurred. Therefore, this article shows that it needs to invite persons other than the "usual advocacy instances", namely those who can prevent anytime, anywhere before the violence began, to take their significant roles to prevent the violence against women. The person might be a figurant, an observer who is aware of the existing violence. He/she can be anyone, such as bus passengers, passers-by, neighbors and even one's own friends. They are expected to become the active upstanders against the abusers. They are the source of pivotal social support and encouragement for the victim to pass through and encounter the abusers, especially in high urgency, when the victim feels hopeless.

This article was written on the awareness of the importance of the violence eradication mindset and behavior as well as how we all, every one of us other than the victim and offender, can stop it. Based on this reasoning, it is expected for the future that many emerging interventions and scientific studies will combat the domestic violence, starting from attacking mindset of objectification, eradication of verbal abuse to the alliances with upstander.

\section{Conclusion}

This article have shown that verbal abuse, objectification attitudes, and apathy towards the witnessed violence can be coped by giving messages through social media, radio media, every day's clothing attribute such as shirts and pins that can be carried anywhere. A Handbook of Violence Prevention gives insight, knowledge, and sensitivity to the surrounding people about the actual and potential domestic violence incidents. This handbook also provides assistance and support to the (potential) victims. This article calls the readers to participate or to initiate the creative violence prevention 
campaigns as much as possible.

However, intervention programs designed in this article is still lack of considering the indigenous cultural context, especially that of the indigenous traditions and local values maintaining gender-based violence. Before the intervention, it is advised for the future researchers to conduct preliminary studies mapping the traditions and values. That intervention would be done not only based on "pure psychological science", but also by combining it with strong cultural anthropological views. Especially in Indonesia in which the majority still maintains strong values and traditions, it is urgent to pay attention to cultural norms fertilizing prejudices against women. The preliminary research would resemble an analysis conducted by Sev'er and Yurdakul (2001) concerning honor killing, i.e. the murder of women (no matter what age) by amorphous reasons, that is attributed to be close with a system of religious beliefs controlling women held by rural population in Turkey.

\section{Acknowledgment}

We thank the PULIH Foundation, Norcahyo Waskito, Jackie Viemilawati, Irma S. Martam, and the promoted New Men Movement program, that, during 2014, has provided training support to us to carry out concrete actions of social intervention based on gender perspective, ecological models, and special consideration of power relations between men and women.

\section{References}

Aisyah, S., \& Parker, L. (2014). Problematic conjugations: Women's agency, marriage and domestic violence in Indonesia. Asian Studies Review, 38(2), 205-223. http://dx.doi.org/10.1080/10357823.2014.899312

Alhabib, S., Nur, U., \& Jones, R. (2010). Domestic violence against women: Systematic review of prevalence studies. Journal of Family Violence, 25(4), 369-382. http://dx.doi.org/10.1007/s10896-009-9298-4

Banyard, V. L. (2008). Measurement and correlates of prosocial bystander behavior: The case of interpersonal violence. Violence and Victims, 23(1), 83-97. http://dx.doi.org/10.1891/0886-6708.23.1.83

Banyard, V. L., Moynihan, M. M., \& Plante, E. G. (2007). Sexual violence prevention through bystander education: An experimental evaluation. Journal of Community Psychology, 35(4), 463-481. http://dx.doi.org/10.1002/jcop.20159

Burke, P. J. (2006). Contemporary social psychological theories. California: Stanford University Press.

Buunk, A. P., \& Van Vugt, M. (2013). Applying social psychology: From problems to solutions. London: SAGE Publications. Ltd.

Carey, D., Jr., \& Torres, M. G. (2010). Precursors to femicide: Guatemalan women in a vortex of violence. Latin American Research Review, 45(3), 142-164.

Chang, J., Berg, C. J., Saltzman, L. E., \& Herndon, J. (2005). Homicide: A leading cause of injury deaths among pregnant and postpartum women in the United States, 1991-1999. American Journal of Public Health, 95(3), 471-477. http://dx.doi.org/10.2105 \%2FAJPH.2003.029868

Cismaru, M., Jensen, G., \& Lavack, A. M. (2010). If the noise coming from next door were loud music, you'd do something about it. Journal of Advertising, 39(4), 69-82. http:// dx.doi.org/10.2753/JOA0091-3367390405

Coker, A. L., Cook-Craig, P. G., Williams, C. M., Fisher, B. S., Clear, E. R., Garcia, L. S., \& Hegge, L. M. (2011). Evaluation of Green Dot: An active bystander intervention to reduce sexual violence on college campuses. Violence Against Women, 17(6), 777-796. http://dx.doi.org/10.1177/1077801211410264

Coker, A. L., Fisher, B. S., Bush, H. M., Swan, S. C., Williams, C. M., Clear, E. R., \& DeGue, S. (2014). Evaluation of the Green Dot bystander intervention to reduce interpersonal violence among college students across three campuses. Violence Against Women, 1-21, http://dx.doi.org/10.1177/1077801214545284

Cook-Craig, P. G., Millspaugh, P. H., Recktenwald, E. A., Kelly, N. C., Hegge, L. M., Coker, A. L., \& Pletcher, T. S. (2014). From empower to Green Dot successful strategies and lessons learned in developing comprehensive sexual violence primary prevention programming. Violence Against Women, 20(10), 1162-1178. http://dx.doi.org/10.1177/1077801214551286

Dani, A. (2006). Kekerasan verbal pada anak lebih sakit dibanding perkosaan. Retrieved from http://www.detiknews.com/index.php/detik .read/tahun/2006/bulan/08/tgl/15/time/085611/idnews/656241/idkanal/10 \& http://www.arsip.net/id/link.php?lh=UwpXXARcBVFW

Hartono, B. (2014). Bentuk perlindungan hukum terhadap perempuan pelapor selaku saksi korban kekerasan dalam rumah tangga. Keadilan Progresif, 5(1). Retrieved from http://jurnal.ubl.ac.id/index.php/KP/article/view/436

Hayati, E. N., Eriksson, M., Hakimi, M., Högberg, U., \& Emmelin, M. (2013). 'Elastic band strategy': Women's lived experiences of coping with domestic violence in rural Indonesia. Global Health Action, 6. http://dx.doi.org/10.3402/gha.v6i0.18894

Healey, L., Humphreys, C., \& Howe, K. (2013). Inclusive domestic violence standards: Strategies to improve interventions for women with disabilities? Violence and Victims, 28(1), 50-68. http://dx.doi.org/10.1891/0886-6708.28.1.50

Iskandar, Z. (2010). Hubungan antara sikap terhadap diskriminasi gender dengan pelecehan seksual pada mahasiswa (Unpublished thesis). Unika Soegijapranata, Semarang, Jawa Tengah, Indonesia.

Koon, J. A. (2013). Masculinity and bystander helping behavior: A study of the relationship between conformity to masculine norms and bystander interventions (Unpublished dissertation). The University of lowa, US. Retrieved from http://ir.uiowa.edu/cgi/view 
content.cgi?article $=5004 \&$ context $=$ etd

Lamont, R. (2013). Beating domestic violence? Assessing the EU's contribution to tackling violence against women. Common Market Law Review, 50(6), 1787-1807.

Ludemir, A. B., Lewis, G. H., Valongueiro, S. A., de Araújo, T. V., \& Araya, R. (2010). Violence against women by their intimate partner during pregnancy and postnatal depression: A prospective cohort study. The Lancet, 376(9744), 903-910. http://dx.doi.org/ 10.1016/S0140-6736(10)60887-2

Marchira, C. R., Amylia, Y., Winarso, M. S. (2007). Hubungan kekerasan dalam rumah tangga dengan tingkat kecemasan pada wanita. Berita Kedokteran Masyarakat, 23(3), 119-123.

McCauley, H. L., Tancredi, D. J., Silverman, J. G., Decker, M. R., Austin, S. B., McCormick, M. C., Virata, M. C., \& Miller, E. (2013). Gender-equitable attitudes, bystander behavior, and recent abuse perpetration against heterosexual dating partners of male high school athletes. American Journal of Public Health, 103(10), 1882-1887. http://dx.doi.org/10.2105/AJPH.2013.301443

McDonald, P., \& Flood, M. G. (2012). Encourage. Support. Act! Bystander approaches to sexual harassment in the workplace. University of Wollongong for the Australian Human Rights Commission. Retrieved from https://www.humanrights.gov.au/sites/default/files/ content/sexualharassment/bystander/bystander june2012.pdf

Paramita, D. P. (2010). Hubungan tingkat pengetahuan tentang dismenorea dengan perilaku penanganan dismenorea pada siswi SMK YPKK I Sleman Yogyakarta. (Unpublished thesis). Universitas Negeri Sebelas Maret, Surakarta, Indonesia. Retrieved from http://eprints.uns.ac.id/195/1/165033008201011451.pdf

Powell, A. (2011). Review of bystander approaches in support of preventing violence against women. VHP Carlton, Victoria, Australia: Victorian Health Promotion Foundation (VicHealth). Retrieved from https://www.vichealth.vic.gov.au/ /media/resourcecentre/ publicationsandresources/pvaw/review\%20of\%20bystander\%20approaches\%203\%20may_final_with\%20cover.ashx

Ribka, D. (1998). Pangemaran, Tindakan Kekerasan Terhadap Perempuan Dalam Keluarga: Hasil Penelitian di Jakarta. Jakarta: Program Studi Kajian Wanita Program Pasca Sarjana, Universitas Indonesia.

Rifka Annisa. (1995). Kekerasan terhadap perempuan: Laporan penelitian. Yogyakarta: Rifka Annisa Women's Crisis Center.

Salazar L. F., Vivolo-Kantor, A., Hardin, J., \& Berkowitz, A. A. (2014). A web-based sexual violence bystander intervention for male college students: Randomized controlled trial. Journal of Medical Internet Research, 16(9), e203. http://dx.doi.org/10.2196 \%2Fjmir.3426

Sarookhani, B., \& Daneshian, F. (2014). The survey of reasons and parameters of domestic violence against the women. Kuwait Chapter of the Arabian Journal of Business and Management Review, 3(11), 144-153.

Sev'er, A., \& Yurdakul, G. (2001). Culture of honor, culture of change: A feminist analysis of honor killings in rural Turkey. Violence Against Women, 7(9), 964-998. http://dx.doi.org/ 10.1177/10778010122182866

Smith, G. (2011). Hidden marks: A study of women students' experiences of harassment, stalking, violence and sexual assault. Retrieved from http://www.nus.org.uk/Global/NUS_hidden_marks_report_2nd_edition_web.pdf

Tajel, H. (1978). Social categorization, social identity and social comparisons. In H. Tajfel (Ed.), Differentiation between social groups (pp. 61-76). London: Academic Press.

Tisyah, D. W., \& Rochana, E. (2013). Analisis kekerasan pada masa pacaran (dating violence). Jurnal Sociologie, 1(1), 1-9. Retrived from http://pshi.fisip.unila.ac.id/jurnal/files/journals/5/articles/199/public/199-618-1-PB.pdf

Tucker-Ladd, C. (2011). Anger and aggression. Psychological Self-help. Retrieved from http://www.psychologicalselfhelp.org/Chapter7/ chap7_1.html

Wahed, T., \& Bhuiya, A. (2007). Battered bodies \& shattered minds: Violence against women in Bangladesh. Indian Journal of Medical Research, 126(4), 341-354.

Windiani, R., \& Astuti, P., Fitriyah, \& Hermini. (2013). Peran Pemerintah Kota Semarang dalam memberikan perlindungan dan keadilan untuk korban KDRT. Journal of Politic and Government Studies, 2(3), 496-510. Retrieved from http://download.portalgaruda. org/article.php?article $=72903 \& v a l=4924$ 